\title{
Localization of 'Candidatus Endobugula sertula' and the bryostatins throughout the life cycle of the bryozoan Bugula neritina
}

\author{
Koty H Sharp ${ }^{1,4}$, Seana K Davidson ${ }^{2}$ and Margo G Haygood ${ }^{1,3}$ \\ ${ }^{1}$ Marine Biology Research Division, Scripps Institution of Oceanography, University of California, San Diego, \\ La Jolla, CA, USA; ${ }^{2}$ Department of Civil and Environmental Engineering, University of Washington, Seattle, \\ WA, USA and ${ }^{3}$ Center for Marine Biotechnology and Biomedicine, Scripps Institution of Oceanography, \\ University of California, San Diego, La Jolla, CA, USA
}

\begin{abstract}
'Candidatus Endobugula sertula,' the uncultivated $\gamma$-proteobacterial symbiont of the marine bryozoan Bugula neritina, synthesizes bryostatins, complex polyketides that render $B$. neritina larvae unpalatable to predators. Although the symbiosis is well described, little is known about the locations of ' $E$. sertula' or the bryostatins throughout larval settlement, metamorphosis and early development. In this study, we simultaneously localized ' $E$. sertula' and the bryostatins in multiple stages of the $B$. neritina life cycle, using a novel bryostatin detection method based on its known ability to bind mammalian protein kinase $\mathrm{C}$. Our results suggest that the bryostatins are deposited onto the exterior of $B$. neritina larvae during embryonic development, persist on the larval surface throughout metamorphosis and are shed prior to cuticle formation. During metamorphosis, ' $E$. sertula' remains adhered to the larval pallial epithelium and is incorporated into the preancestrula cystid tissue layer, which ultimately develops into a bud and gives rise to the next zooid in the colony. Colocalization of bryostatin signal with aggregates of ' $E$. sertula' in buds of ancestrulae suggested new synthesis of bryostatins in ancestrulae. In adult $B$. neritina colonies, symbiont microcolonies were observed in the funicular cords of rhizoids, which likely result in asexual transmission of ' $E$. sertula' to regenerated colonies. Furthermore, bryostatin signal was detected on the surface of the rhizoids of adult $B$. neritina colonies. Through simultaneous localization of the bryostatins and the 'E. sertula,' we determined how ' $E$. sertula' is transmitted, and identified shifts in bryostatin localization throughout the life cycle of the host $B$. neritina.
\end{abstract}

The ISME Journal (2007) 1, 693-702; doi:10.1038/ismej.2007.78; published online 11 October 2007

Subject Category: microbe-microbe and microbe-host interactions

Keywords: Bugula neritina; bryostatin localization; bryostatins; invertebrate-bacterial symbiosis; larval development

\section{Introduction}

The bryozoan Bugula neritina (Cheilostomata, Cellularoidea) harbors the symbiotic gammaproteobacterium 'Candidatus Endobugula sertula' ('E. sertula') (Haygood and Davidson, 1997). ' $E$. sertula' produces the bryostatins (Davidson et al., 2001), a group of complex polyketides that protect $B$. neritina larvae from predation (Lindquist

Correspondence. Current address: MG Haygood, Department of Environmental and Biomolecular Systems, OGI School of Science and Engineering, Mail Code OGI 100, Oregon Health and Science University, 20000 NW Walker Road, Beaverton, OR 97006-8921, USA.

E-mail: haygoodm@ebs.ogi.edu

${ }^{4}$ Current address: Smithsonian Marine Station at Fort Pierce, 701 Seaway Drive, Fort Pierce, FL 34949, USA.

Received 2 July 2007; revised 30 August 2007; accepted 3 September 2007; published online 11 October 2007 and Hay, 1996; Lopanik et al., 2004). The bryostatins, first isolated from $B$. neritina (Pettit et al., 1982), also show potential for treatment of Alzheimer's disease and a variety of cancers (Kraft et al., 1986; Parkinson et al., 1994; Sun and Alkon, 2005, 2006; Kuzirian et al., 2006). Research over the past decade has confirmed the symbiotic source of the bryostatins, identified the bryostatin biosynthetic genes from ' $E$. sertula' and determined that the bryostatins provide chemical defense for $B$. neritina larvae. Adult $B$. neritina colonies are sessile and physically protected by a chitinous cuticle, but their swimming, softbodied larvae are vulnerable to predators. $B$. neritina larvae possess both relatively high levels of bryostatins and ' $E$. sertula.' Larvae containing their full complement of bryostatins are rejected by fish predators (Lindquist and Hay, 1996). Antibiotic treatments, which reduced ' $E$. sertula' density in $B$. neritina adult colonies, decreased bryostatin 
concentration in B. neritina, and lowered expression of $\operatorname{bry} A$, a portion of the bryostatin biosynthetic gene cluster (Davidson et al., 2001; Hildebrand et al., 2004; Sudek et al., 2007). Such antibiotic treatments of $B$. neritina did not alter the growth, settlement or metamorphosis of $B$. neritina (Davidson et al., 2001; Lopanik et al., 2004), but the reduction of bryostatins did increase the palatability of the larvae to fish (Lopanik et al., 2004).

Bryostatins occur naturally in low concentrations in B. neritina, hindering development of the drug for clinical treatments. In addition, the inability to cultivate ' $E$. sertula' to date has hampered efforts to improve bryostatin production. Factors regulating the growth and transmission of bacterial cells and the bryostatin production within the host during metamorphosis, early development and adult colony growth remain unknown. A better understanding of the biology of ' $E$. sertula' growth and bryostatin production in the host in situ is necessary in order to enable further biochemical characterization of the microenvironments that support both 'E. sertula' growth and bryostatin synthesis. In this study, we determined where ' $E$. sertula' and the bryostatins are located within $B$. neritina throughout the life cycle.

$B$. neritina reproduces both sexually and asexually to form a colony made up of many clonal individuals (Figure 1). Fertilization occurs internally, and developing embryos are brooded on the parent colony in a protective ovicell chamber. After embryonic development, the ciliated, lecithotrophic larvae are released into the seawater where they remain from 2 to $12 \mathrm{~h}$ before settling on a substrate. The swimming larvae contain the symbiont ' $E$. sertula' in the pallial sinus, a groove on the aboral pole (Woollacott, 1981; Haygood and Davidson, 1997). During the dispersal period, the larvae are especially susceptible to predation, but the bryostatins offer protection. After settling onto a substrate,

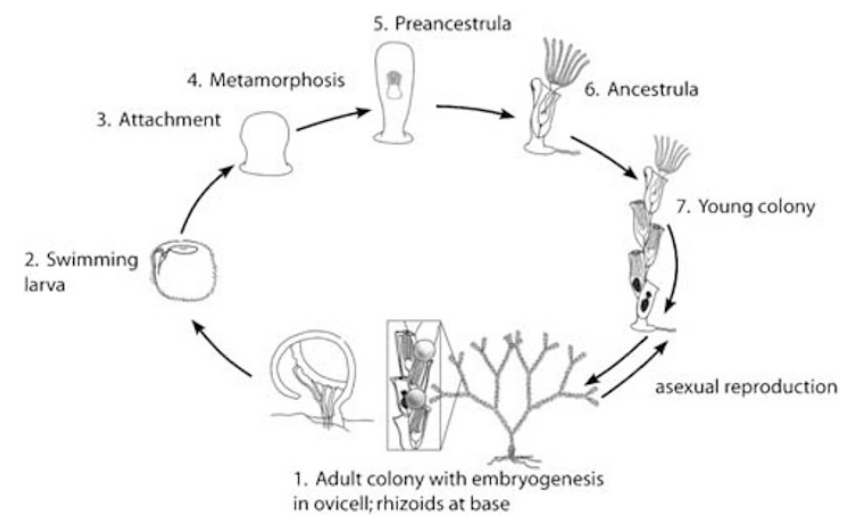

Figure 1 Life cycle of the bryozoan Bugula neritina. 1 Adult $B$. neritina with embryos in ovicell chambers, and ability to form new zooids from rhizoids (hold-fast strands). 2 Swimming larvae released from ovicells remain in water column for a variable period of time. 3-6 Larval settlement, metamorphosis and development into the ancestrula. Continued budding of new zooids occurs to form a mature colony. a $B$. neritina larva undergoes metamorphosis and develops into the first feeding unit of a colony, the ancestrula, which is coated by a protective chitinous cuticle. The ancestrula subsequently gives rise to a colony via asexual reproduction from the ancestrular cystid (Woollacott and Zimmer, 1977). In the adult colony, the outer most tips are the newest buds, and the base the oldest portion of the colony. The rhizoids, the holdfast of the colony, grow out from the colony base and continue to lengthen. Feeding zooids can bud from rhizoids after mechanical disturbance or senescence (Gordon, 1977).

During the larval metamorphic transitions and subsequent adult colony asexual divisions, the location and movement of the bacteria remains enigmatic. Possibly, 'E. sertula' cells are transmitted from one zooid to the next during division via the funicular cords, a network of tubules running throughout the colony. Transmission electron microscopy has shown the presence of bacteria in channels within the funicular system (Woollacott and Zimmer, 1977), but to date, these bacteria remain unidentified.

Not only are bacteria transmitted throughout the colony, but the bryostatins clearly are transmitted and do not remain solely in the bacterial cells. Bryostatins are detected throughout the entire larva, even though the bacteria are restricted to the pallial sinus (Davidson, 1999). Furthermore, the distribution of bryostatins within the adult colony varies such that bryostatins are more concentrated in the growing tips and the rhizoids (Davidson, 1999), and lowest in the older, basal portions of well-established colonies (a few months old). Levels of the symbiont 16S rRNA gene and of a portion of the bryostatin biosynthesis gene cluster were also highest in the tips, but low in the rhizoids (Davidson, 1999), indicating that the location of the bryostatins may not be restricted to the location of the ' $E$. sertula' cells. Mechanisms of bryostatin translocation throughout the colony, including delivery to the developing embryos, remain to be determined.

Although several studies have successfully used visualization techniques to localize natural products in situ in various marine invertebrates (Gillor et al., 2000; Salomon et al., 2001; Schroder et al., 2006), the methods used in those studies are not feasible for use in bryostatin localization. In order to detect bryostatins in situ, we developed a method based on their clinical molecular target, mammalian protein kinase C (PKC). The anti-cancer activity of the bryostatins is due to the high affinity of bryostatins for the phorbol binding site on mammalian PKC (DeVries et al., 1988; Wender et al., 1988). In our method, the bacterial cells and the bryostatins are visualized simultaneously-the PKC-based detection method is used to localize bryostatins, in conjunction with fluorescence in situ hybridization (FISH) for ' $E$. sertula' localization. The simultaneous detection of bacteria and bryostatins showed (1) the location of the bacterial symbionts through the early 
metamorphic stages of the host, (2) the location of the symbionts in adult structures and (3) the presence of bryostatins in relation to bacterial symbionts and host structures. The results were used to construct a model of $E$. sertula proliferation and bryostatin biosynthesis throughout the development of the symbiosis.

\section{Materials and methods}

B. neritina collection and larval harvesting

B. neritina colonies were collected via SCUBA or snorkel from the Scripps Institution of Oceanography Pier, La Jolla, CA, USA, and maintained in flowing ambient temperature seawater tanks. Adult colonies were separated into branches with ovicells, branches without ovicells and rhizoids. After separation, samples were rinsed with sterile-filtered seawater $(0.2 \mu \mathrm{m}$ filter $)$, fixed in $4 \%$ paraformaldehyde- $20 \mathrm{mM}$ sodium phosphate $\left(15 \mathrm{mM} \mathrm{Na}_{2} \mathrm{HPO}_{4}\right.$, $\left.5 \mathrm{mM} \mathrm{NaH}_{2} \mathrm{PO}_{4}, \mathrm{pH} 7.4\right)-0.5 \mathrm{M} \mathrm{NaCl}$ overnight at $4{ }^{\circ} \mathrm{C}$, washed in buffer and then stored in $70 \% \mathrm{EtOH}$ at $-20^{\circ} \mathrm{C}$. Adult $B$. neritina were kept in ambient running seawater tanks with a 12/12-h light-dark cycle. Larvae were collected in the morning by Pasteur pipette and placed on ice in sterile-filtered seawater $(0.2 \mu \mathrm{m}$ filter $)$ in a $15-\mathrm{ml}$ Falcon tube, causing the larvae to fall to the bottom of the tube, allowing decanting of seawater. The larvae were subsequently rinsed three times in sterile-filtered seawater to reduce particles and contaminating bacteria, then fixed in buffered $4 \%$ paraformaldehyde (recipe above) and stored in $70 \%$ ethanol at $-20^{\circ} \mathrm{C}$.

B. simplex and B. turrita colonies were collected by hand from floating docks in Eel Pond, Woods Hole, MA, USA, and larvae were processed and fixed in the same manner as the $B$. neritina larvae.

\section{Larval settlement and metamorphosis}

To obtain multiple samples of $B$. neritina at similar developmental stages, $B$. neritina larvae were induced to settle onto microscope slides (Fisherbrand plain, pre-cleaned glass slides) by placing them in 100-mm Petri dishes (polystyrene, Fisherbrand) containing artificial seawater with twice the normal $\mathrm{KCl}$ concentration as seawater $\left(50 \mathrm{mM} \mathrm{MgSO}_{4}\right.$, $10 \mathrm{mM} \mathrm{CaCl}, 300 \mathrm{mM} \mathrm{NaCl}, 10 \mathrm{mM} \mathrm{KCl}$ ) (Yool et al., 1986). The larvae were placed in the dark, and after approximately $1.25 \mathrm{~h}$, the number of settled larvae was counted (average 80\% settlement rate) and the settlement solution was replaced with sterile-filtered artificial seawater.

After attachment to the slides, B. neritina larvae began to undergo metamorphosis. Metamorphosis and early development was observed with a dissection scope over the following $96 \mathrm{~h}$ during which time samples were identified and fixed at the following events: (1) the attachment of larvae to the glass slide and the loss of their outer layer of ciliated cells, (2) the eversion of the larval pallial epithelium, (3) the reversion of the pallial epithelium and the internalization of the larval apical disc, (4) the elongation and differentiation of larvae into the preancestrula and (5) the development of the first ancestrula, consisting of a newly emerging bud for the second zooid (as outlined in Table 1 and in Gordon, 1977; Woollacott and Zimmer, 1978). Larvae at all post-settlement stages were fixed and processed on glass slides (see below).

\section{Symbiont localization by fluorescence in situ hybridization}

B. neritina samples were incubated in hybridization buffer (35\% formamide, $0.9 \mathrm{M} \mathrm{NaCl}, 20 \mathrm{mM}$ Tris-HCl ( $\mathrm{pH} 7.4), 0.01 \%$ sodium dodecyl sulfate) either in microfuge tubes or directly on the glass slides (attached developmental stages). To identify the ' $E$. sertula' cells and other eubacterial cells, we added the following oligonucleotide probes (outlined in Table 2) at a final concentration of $5 \mathrm{ng}^{-1} \mathrm{l}^{-1}$ in hybridization buffer: CY5-Es1253 (specific for ' $E$. sertula'; Haygood and Davidson, 1997); the negative control probe CY5-Eg1253, which has a single-base

Table 1 Major $B$. neritina metamorphosis and early developmental stages examined in this study

\begin{tabular}{|c|c|c|}
\hline $\begin{array}{l}\text { Stage } \\
\text { number }\end{array}$ & $\begin{array}{l}\text { Time } \\
(h)^{\mathrm{b}}\end{array}$ & Morphological description \\
\hline 1 & - & Adult colony with ovicells and rhizoids \\
\hline 2 & 0 & Ciliated, free-swimming larvae \\
\hline 3 & 1.25 & $\begin{array}{l}\text { Attached larva; pallial epithelium } \\
\text { evagination toward oral surface }\end{array}$ \\
\hline 4 & 2 & $\begin{array}{l}\text { Elongation into upright pillar; } \\
\text { internalization of apical disc and larval } \\
\text { pallial epithelium }\end{array}$ \\
\hline 5 & 48 & $\begin{array}{l}\text { Further elongation; formation of chitinous } \\
\text { cuticle; initiation of histogenic } \\
\text { differentiation }\end{array}$ \\
\hline 6 & 96 & $\begin{array}{l}\text { Lophophore functional; bud for second } \\
\text { autozooid starting to develop }\end{array}$ \\
\hline
\end{tabular}

aStages corresponding to stage numbers in Figure 1.

${ }^{\mathrm{b}}$ After addition of high $(\mathrm{KCl})$ seawater.

Table 2 Oligonucleotide probes used in this study

\begin{tabular}{lll}
\hline Probe name & Sequence $\left(5^{\prime}-3^{\prime}\right)$ & Reference \\
\hline EUB338 & $5^{\prime}$-GCTGCCTCCCGTAGGAGT-3' & $\begin{array}{l}\text { Amann } \\
\text { et al. } \\
(1990)\end{array}$ \\
Es1253 & $5^{\prime}$-CATCGCTGCTTCGCAACCC-3' & $\begin{array}{l}\text { Haygood } \\
\text { and } \\
\text { Davidson } \\
(1997) \\
\text { Egl1253(EsNON) }\end{array}$ \\
& $5^{\prime}$-CATCACTGCTTCGCAACCC-3' & $\begin{array}{l}\text { Lim and } \\
\text { Haygood } \\
(2004)\end{array}$ \\
\hline
\end{tabular}


mismatch to the ' $E$. sertula'-specific probe (Lim and Haygood, 2004); and EUB338 (general eubacterial probe; Amann et al., 1990). Samples were hybridized with probes for $2 \mathrm{~h}$ in a humidified chamber at $46{ }^{\circ} \mathrm{C}$, then washed at $48{ }^{\circ} \mathrm{C}$ in wash buffer $(0.7 \mathrm{M}$ $\mathrm{NaCl}, 20 \mathrm{~mm}$ Tris-HCl (pH 7.4), $50 \mathrm{~mm}$ EDTA, 0.01\% sodium dodecyl sulfate) for $20 \mathrm{~min}$, then again washed briefly in water purified with a Milli-Q system (Millipore, Bedford, MA, USA), air-dried and then mounted in VectaShield (Vector Labs, Burlingame, CA, USA) for visualization.

\section{Bryostatin localization}

Bryostatins were detected by initially binding PKC to the bryostatins in the intact $B$. neritina stages, then visualizing the PKC binding locations using fluorescence-based antibody detection. Briefly, the protocol consisted of the following steps: (1) a stock of mouse PKC $\alpha$ was incubated with $B$. neritina samples to bind the bryostatins, (2) bound PKC $\alpha$ was detected with a mouse monoclonal anti-PKC $\alpha$ antibody and (3) the primary antibody (anti-PKC $\alpha$ ) was detected with a fluor-conjugated secondary antibody (Alexa 555-conjugated goat anti-mouse immunoglobulin $\mathrm{G}_{1}$ ).

Swimming larvae were processed in microfuge tubes, and individuals in metamorphosis and early development were processed on glass slides. In the adult colonies, including the rhizoids, samples were sliced with sterile razor blades to ensure penetration of reagents into the interior of $B$. neritina tissue and then processed in microfuge tubes. Fixed $B$. neritina samples $(n=200)$ were incubated for $20 \mathrm{~min}$ in a fresh solution containing $0.5 \mathrm{ng}^{-1} \mathrm{l}^{-1}$ mouse PKC $\alpha$ (Upstate Signaling, Charlottesville, VA, USA), $1 \mathrm{mM}$ dithiothreitol, $1 \%$ wt/vol bovine serum albumin, $40 \mu \mathrm{g} \mathrm{ml}^{-1}$ leupeptin, $150 \mathrm{~mm} \mathrm{NaCl,} 20 \mathrm{mM}$ HEPES and $0.5 \mathrm{mM} \mathrm{Na}_{2}$ EDTA, at $\mathrm{pH}$ 7.5. The samples were washed two times ( $5 \mathrm{~min}$ each) in phosphatebuffered saline (PBS; $10 \mathrm{mM} \mathrm{Na} \mathrm{HPO}_{4}, 2.7 \mathrm{mM} \mathrm{KCl}$, $140 \mathrm{~mm} \mathrm{NaCl}, \mathrm{pH}$ 7.4), then incubated in PBS with M4 monoclonal anti-mouse PKC $\alpha$ (Upstate Signalling) at a final concentration of $10 \mu \mathrm{g} \mathrm{ml}^{-1}$ overnight $(\sim 16 \mathrm{~h})$.

The samples were washed in PBS three times ( 5 min each), incubated in a 1\% gamma globulin/ PBS blocking solution for $5 \mathrm{~min}$ and then with a secondary antibody $(5 \mu \mathrm{g} / \mathrm{ml}$; Alexa 555-conjugated goat anti-mouse immunoglobulin $\mathrm{G}_{1}$; Invitrogen, Carlsbad, CA, USA) in the blocking solution for $2 \mathrm{~h}$ in the dark and finally rinsed (two rinses of $5 \mathrm{~min}$ each) in PBS. All steps were carried out at room temperature. For simultaneous bryostatin and ' $E$. sertula' localization, bryostatin localization was first performed on fixed $B$. neritina samples, and then the FISH detection protocol was applied to the samples. After completion of the FISH protocol, bryostatin and symbiont localization were simultaneously visualized with a Zeiss Pascal laser scanning confocal microscope. Images were captured with
ImageBrowser image-acquisition software (Zeiss, Oberkochen, Germany).

The negative control probe for oligonucleotide probe specificity in the FISH protocol was a singlebase mismatch probe. In the bryostatin localization protocol, the negative control included the detection protocol without addition of PKC $\alpha$ to the samples, in order to distinguish PKC-dependent signal from autofluorescence and nonspecific antibody binding. The negative control images were captured with similar gain settings as in the images captured from the experimental treatments.

\section{Testing the bryostatin localization protocol}

Among Bugula species, there are a few that possess bryostatins and symbionts that belong to the 'Endobugula' genus, and others that appear to lack both 'Endobugula' and the bryostatins. Therefore, it was possible to test the bryostatin localization method on different Bugula species with known variation in 'Endobugula' and bryostatins. We used $B$. simplex and B. turrita as positive and negative controls, respectively, for the PKC-based bryostatin detection method. B. simplex, collected in Woods Hole, MA, USA, harbors the symbiont 'Candidatus Endobugula glebosa' in the larval pallial sinus (Lim and Haygood, 2004). Extracts of B. simplex exhibit bryostatin-like activity, and genes homologous to the bryostatin polyketide synthase biosynthetic genes in 'E. sertula' have been isolated from 'E. glebosa' (Lim and Haygood, 2004), suggesting that the B. simplex'E. glebosa' symbiosis is likely a chemical defense symbiosis analogous to the $B$. neritina-'E. sertula' association. $B$. turrita has been shown to lack bacteria in the pallial sinus (Woollacott, 1981) and does not appear to contain bryostatins (Lim and Haygood, 2004).

\section{Results}

Bryostatin detection by PKC binding

The PKC antibody, serving as a proxy for bryostatin signal, was evenly distributed on the outer surface of $B$. neritina and $B$. simplex larvae, both known to contain bryostatins (Figures 2a and b) (Lim and Haygood, 2004). In the negative control, which lacked the addition of $P K C \alpha$, signal was not detected on $B$. neritina larvae, ovicells or rhizoids (Figures 2c-e). Furthermore, the PKC signal was not detected in larvae of $B$. turrita (Figure 2f), known to lack bacterial symbionts and bryostatin-like molecules (Woollacott, 1981; Lim and Haygood, 2004). No PKC signal was detectable in the interior of the adult colonies.

\section{Localization of 'E. sertula' and bryostatins in B. neritina}

Although the host tissue exhibits autofluorescence, bacterial cells were visualized by FISH and confocal 
microscopy within the ovicells, larvae and subsequent developmental stages; controls were used to differentiate autofluorescence from signal. Figure 3a shows a schematic of a $B$. neritina ovicell containing a developing embryo, connected to the maternal zooid by a bundle of funicular cords. Strong PKC signal was detected at the junction between the ovicell and the feeding zooid, and in a sheath around the developing larva within the ovicell (Figure 3b). Symbiont cells were present near the concentration of PKC signal at the base of the ovicell (Figure $3 \mathrm{~b}$ ) and in the funicular cords leading to ooecial epithelium and embryo (Figure 3c). A negative control (no PKC added) showed no signal in or on the ovicells (Figure 3d). After larval release, symbionts and PKC signal were not detectable in the empty ovicell (not shown).

' $E$. sertula' localization demonstrated that the symbiont was present in the pallial sinus, as shown previously (Haygood and Davidson, 1997), and

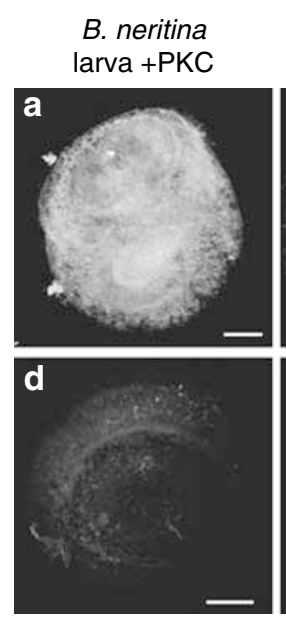

B. neritina larva - PKC
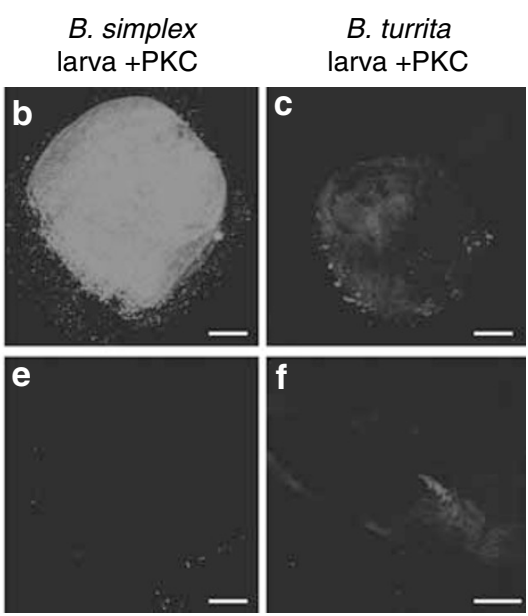

B. neritina ovicell- PKC

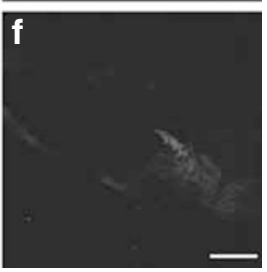

B. neritina rhizoid - PKC
Figure 2 Bryostatin detection in Bugula species. (a-c) Bugula larvae incubated with PKC $\alpha$, anti-PKC primary antibody and secondary antibodies. (c) B. turrita larva, negative control (this species does not contain bryostatins). White, Alexa 555-conjugated goat anti-mouse immunoglobulin G signal. (d-f) Negative controls for $B$. neritina larva, ovicell and rhizoid, incubated only with anti-PKC and Alexa 555-conjugated goat anti-mouse immunoglobulin G (no PKC added). Scale bars $=20 \mu \mathrm{m}$. the PKC signal appeared evenly distributed on the surface of the larva (Figure 4a). Shortly after attachment of the larval oral pole, transitory larval tissues involute toward the center of the metamorphosing individual, drawing the pallial epithelium out of its groove and stretching it out and around the larva toward the oral (settling) surface. During the pallial epithelium migration, 'E. sertula' cells (Es1253 probe/Eub338 probe; orange) appeared in a ring corresponding to the original bacterial attachment site, apparently following the movement of the pallial epithelium (Figure 4b).

The next phase of metamorphosis involves reversion of the pallial epithelium toward the aboral pole, contraction of the pallial epithelium around the apical disc and ultimately involution into the developing $B$. neritina individual. After involution, aggregates of ' $E$. sertula' cells were observed within internalized pallial epithelium in the newly formed preancestrula (Figure 4c). In contrast, the PKC signal remained on the exterior of the individual through this reversion and elongation. After further elongation, the PKC signal was present on most of the surface of the developing individual, but the aboral end lacked the coating (Figure 4d). After development of the chitinous exoskeleton on the preancestrula, the PKC signal no longer appeared on the exterior but only on the glass slide on which the larva settled (Figure 4e). In the preancestrula, ' $E$. sertula' aggregates occurred in the cystid, near the apical tip surrounding the developing lophophore (Figure 4f). In all examined preancestrulae $(n=100)$, PKC labeling was consistently too low for detection.

In fully developed ancestrulae with feeding lophophores, 'E. sertula' aggregates were present in the buds that ultimately form the second zooid (Figure 5a). PKC signal was consistently detected around the aggregates of ' $E$. sertula' within the buds of the ancestrulae $(n=40)$ (Figure $5 \mathrm{~b})$. In the adult colonies, hybridization with both the ' $E$. sertula'specific probe (CY3-Es1253, red) and the eubacterial probe (FITC-EUB, green) revealed diverse morphotypes of bacteria (green) on the exterior of the rhizoids, but only ' $E$. sertula' was detected in the interior (rhizoid sliced open) of the rhizoid, associated with the funicular cords (Figures 5c and
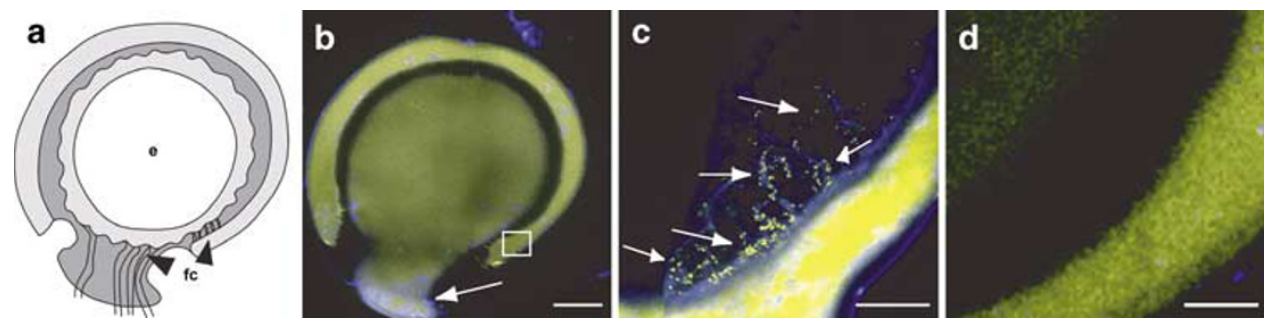

Figure 3 Bryostatin and 'E. sertula' in B. neritina ovicells with embryos. (a) A diagram of an ovicell chamber; fc, funicular cords; e, embryo. (b) PKC signal (blue) around base of ovicell, and in embryonic chamber. (c) Magnification of ovicell. Arrows, 'E. sertula' (yellow) and bryostatins (blue) along funicular cords in ovicell. (d) Negative controls, consisting of negative control probe Egl1253, and PKC antibody alone (no PKC). Scale bar $=50 \mu \mathrm{m}(\mathbf{b}), 20 \mu \mathrm{m}$ (c and d). 


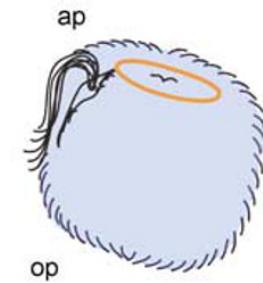

op
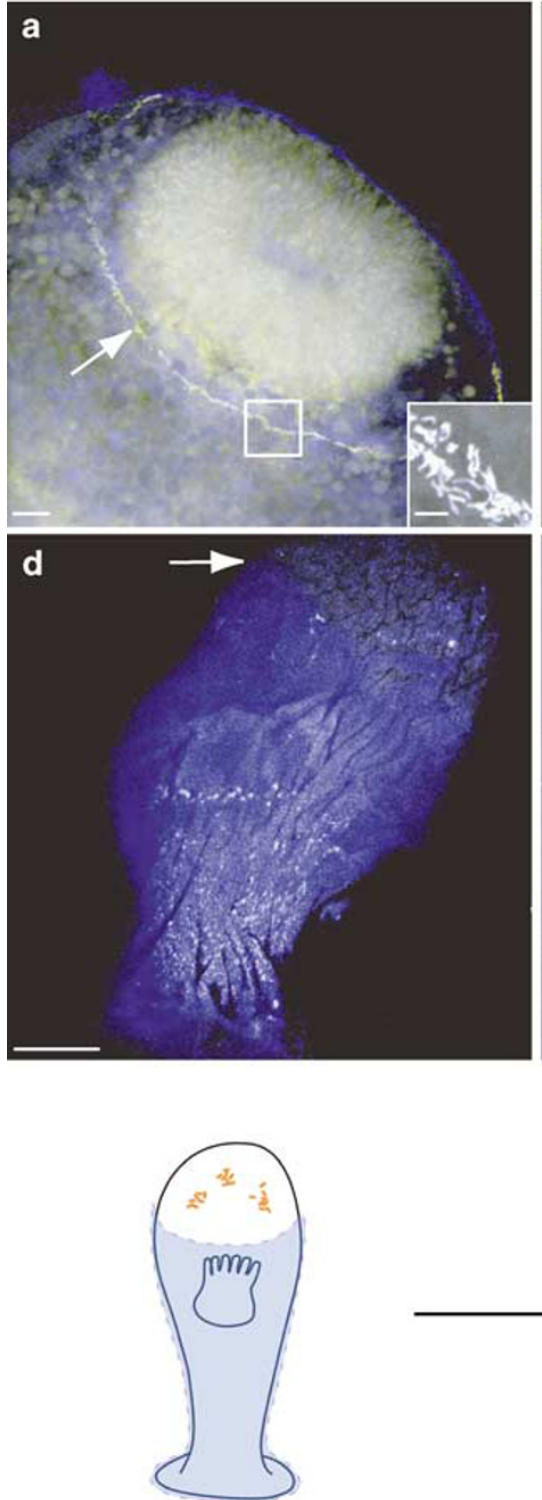

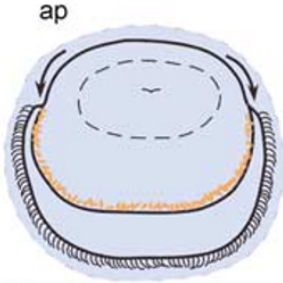

op
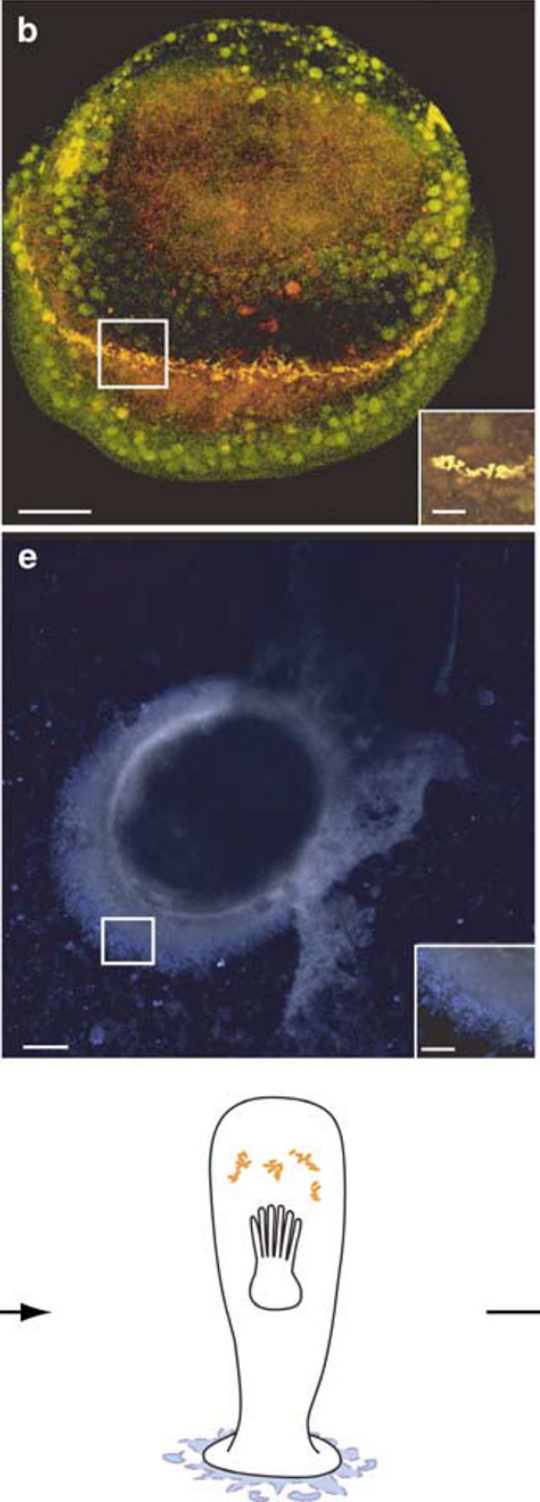
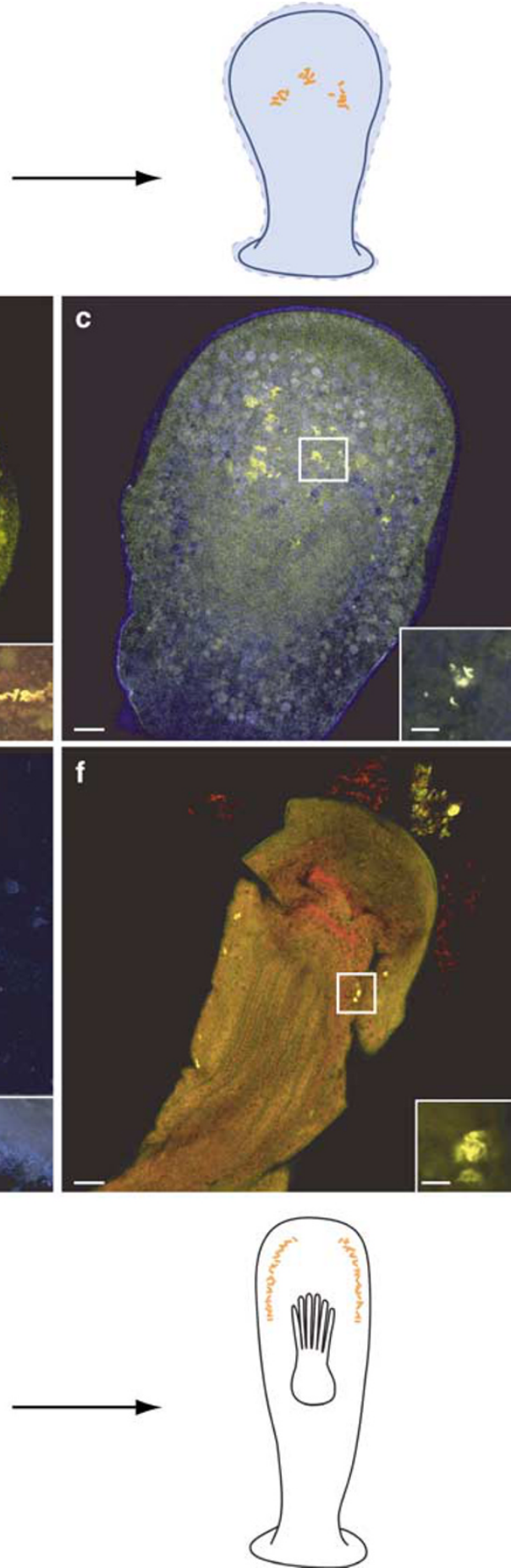

Figure 4 Bryostatin and 'E. sertula' in early developmental stages in B. neritina. (a-f) ' $E$. sertula' cells labeled with CY3-Es1253 probe (yellow); bryostatins labeled with Alexa555-PKC signal (blue), unless otherwise noted. (a) Stage 2, swimming B. neritina larva. Arrow, pallial sinus. Inset, enlargement showing 'E. sertula' cells in pallial sinus. (b) Stage 3, an attached larva; 'E. sertula' cells (orange) duallabeled with CY3-Es1253 (yellow) and CY5-EUB338 (red), visible in ring of pallial epithelium tissue. Inset, enlargement showing ' $E$. sertula' cells. (c-e) Later metamorphosis (stage 4). Internalized ' $E$. sertula' cells (yellow) and PKC signal (blue). (d) White arrow, apicalmost boundary of blue bryostatin signal. (e) PKC signal (blue) present on the settling substrate. Inset, enlargement showing PKC signal (blue). (f) Stage 5, preancestrula. Histogenic differentiation and lophophore formation. 'E. sertula' aggregates (yellow) in the preancestrular cystid. Scale bar $=20 \mu \mathrm{m}$ (a, e and f), $50 \mu \mathrm{m}$ (b-d). Inset scale bars $=5 \mu \mathrm{m}$. op, oral pole; ap, aboral pole.

d). The PKC signal was detected as a contiguous coating (blue) on the exterior of the rhizoids (Figure 5d). An optical cross-section of the rhizoid shows the PKC signal on the rhizoid exterior and the symbiont ' $E$. sertula' inside the rhizoid (Figure 5e). The rhizoids incubated with anti-PKC alone (negative control, no added PKC) displayed only a very faint signal. 
B. neritina ancestrula

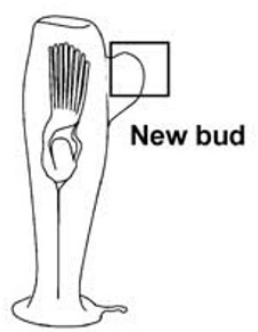

B. neritina adult colony

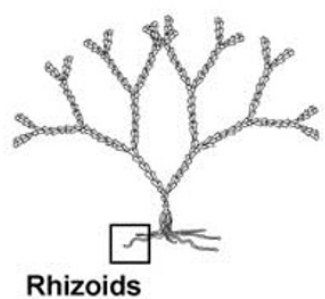

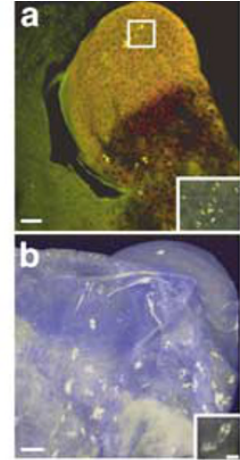

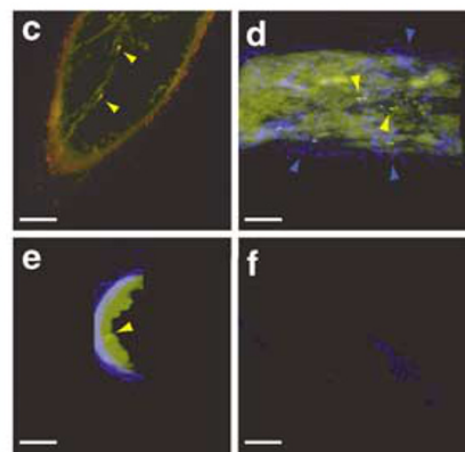

Figure 5 E. sertula and bryostatins in Bugula neritina ancestrulae and rhizoids. (a-f) Orange, 'E. sertula' cells colabeled with both CY3-Es1253 and CY5-EUB338. Red, non-'E. sertula' bacterial cells labeled with EUB338 alone (unless otherwise noted). Blue, PKC signal. (a) Bud extending from a $B$. neritina ancestrula (Stage 6), containing ' $E$. sertula' aggregates, surrounded (b) by PKC signal (blue). (c-f) Rhizoids. Yellow arrows, 'E. sertula' aggregates. (c) Cross-section showing ' $E$. sertula' (orange) in the funicular cords. Red, other eubacteria on the rhizoid cuticle. (d and e) Longitudinal and cross-section view of optical stack from surface to interior. Blue, PKC signal. (f) Longitudinal view of rhizoid negative control treatment (no added PKC). Scale bars $=20 \mu \mathrm{m}$ (a, b), $5 \mu \mathrm{m}$ insets; $50 \mu \mathrm{m}$ (c-f).

\section{Discussion}

This study suggests several shifts in the location of symbiotically produced bioactive metabolites during the life cycle of the host organism. Furthermore, the results have demonstrated the efficacy of a new method for simultaneous in situ detection of a symbiont and an ecologically significant bioactive metabolite. Using FISH to label ' $E$. sertula' and a PKC-based method to detect the bryostatins, we have followed the transmission of 'E. sertula' and determined the spatio-temporal distribution of bryostatins throughout the early life stages of $B$. neritina. A model of the shifts in symbiont and bryostatin localization throughout the development of the symbiosis based on our results is outlined in Figure 6.

The locations of both the bacterial symbionts and the byrostatins demonstrate that the $B$. neritina-' $E$. sertula' association has a delivery system for both the symbionts and the bryostatins to embryos within the ovicell. The concentration of bacteria and

bryostatins within the ovicell around the larva ensures the protection of the larva after release and an inoculum of bacteria for the new colony. The lack of strict colocalization of bryostatins to ' $E$. sertula' within the larvae suggests that bryostatins are not restricted to the location of the symbiont cells in the pallial sinus, and that the bryostatins are loaded onto the larvae during the brooding period in the ovicell. During metamorphosis, the loss of bryostatin signal as the preancestrula grows suggests that new synthesis has not yet begun at this stage. The early developmental period presumably relies on residual bryostatins for defense. The ' $E$. sertula' cells that migrate with the pallial epithelium do not colocalize with bryostatins after they are internalized, perhaps because new synthesis has not yet started. After the feeding ancestrula has matured, bryostatin signal was detected with the bacterial aggregate, the first stage in which bryostatin synthesis in the new colony is visibly detectable. The cause of this lag in symbiotic bryostatin synthesis during early development is unknown. Possibly, a critical density of bacterial cells not achieved during metamorphosis is required to produce bryostatins in detectable levels. Quorum sensing, or cell densitybased regulation of gene expression, is yet to be explored in ' $E$. sertula,' but it is well-known to regulation diverse processes in prokaryotes, including initiation of symbiosis, antibiotic production and biofilm formation (Daniels et al., 2004; Lupp and Ruby, 2005; He and Fuqua, 2006; reviewed in Miller and Bassler, 2001). Our results from this study point to specific host life stages, particularly during embryogenesis, in which bryostatin biosynthesis is likely upregulated. Future studies of bry regulation, including quantitative measurement of bry expression and in situ localization of bry, should target these stages.

The pattern of bryostatin localization is consistent with its function as a predator deterrent for the vulnerable larval stage. Bryostatins were found to be evenly distributed over the larval exterior during the vulnerable dispersal period, consistent with previous conclusions that the bryostatins are associated with the outer layer of $B$. neritina larvae to be most effective as a predator deterrent (Lopanik et al., 2004). The bryostatin signal persisted through the period of settlement and metamorphosis to the ancestrula, prior to formation of the protective chitinous shell. These results corroborate recent findings that although bryostatin concentrations are significantly lower in stages 4 -h and 1-day postsettlement, this correlates with an increase in chitin and carbonate content (Lopanik et al., 2006). As the first zooid developed, the bryostatin signal diminished, corresponding potentially to the increase of surface protection due to the chitin shell. Shortly after this period, bryostatin signal was detected around the bacterial aggregate inside the zooid bud, suggesting that bryostatins would increase to offer some protection to the juvenile colony forming. 


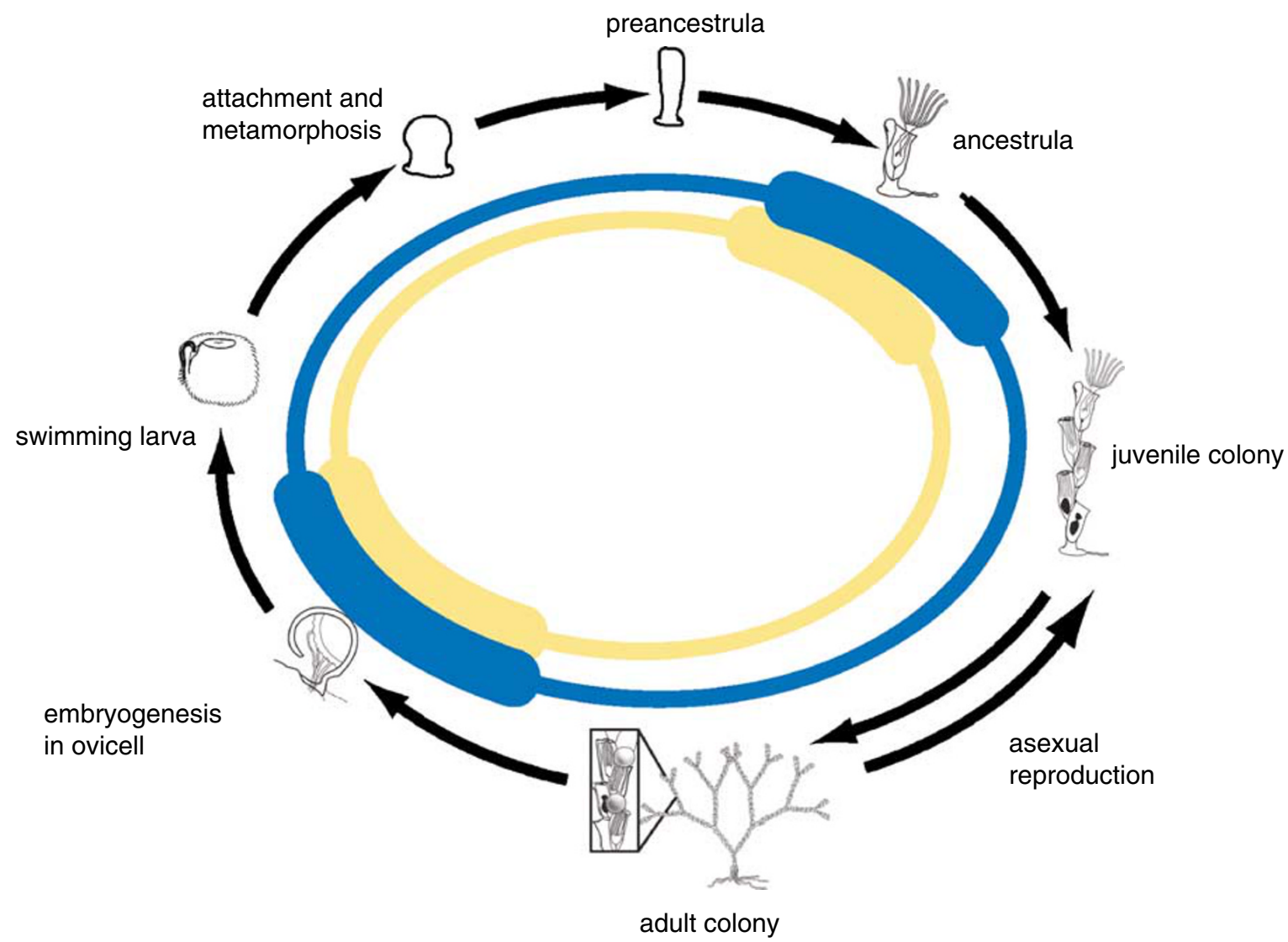

Figure 6 Model of ' $E$. sertula' proliferation and bryostatin levels in B. neritina throughout the life cycle. Yellow, 'E. sertula'; blue, bryostatin. Fine lines, passive transport and steady state growth of ' $E$. sertula' cells; steady rates of bryostatin biosynthesis. Heavy lines, increased ' $E$. sertula' levels and new bryostatin biosynthesis.

Once the metamorphic juvenile reached the preancestrula stage, ' $E$. sertula' aggregates were present within the developing cystid tissue. Our results suggest that in a growing colony, when the cystid forms buds from the preancestrula, symbionts are carried into the next zooid as it forms (Figures 5a and b). Symbiont transmission during asexual bud formation, either from feeding zooids or from rhizoids, likely occurs via the funicular cords since bacterial cells were previously found in the funicular system of adult $B$. neritina (Gordon, 1977) and identified in this study as ' $E$. sertula' in the ovicells and rhizoids by FISH (Figure 5e). Consistent with the hypothesis that the $B$. neritina-'E. sertula' symbiosis is a highly specific relationship (Haygood and Davidson, 1997), only 'E. sertula' cells were detected within the early developmental stages, and the adult by FISH. However, many other bacterial types colonize the external cuticle of colonies, as well as the settlement substrate as shown by the detection of non-' $E$. sertula' cells.

The findings here confirmed that the rhizoids, the anchors of the colony, possess ' $E$. sertula' within the funicular cords, and, corroborating previous bioactivity data (Davidson, 1999), bryostatins on the exterior of the rhizoid cuticle. This, together with an earlier observation that the bioactivity for bryosta- tins is relatively high in the rhizoids, suggests a requirement for chemical protection of the colony anchors. The bryostatins in the rhizoids may function in preventing both predation and fouling. In these highly competitive encrusting communities, space is limited. Protection against grazing and overgrowth by settling larvae or other colonies is critical for success in this community. The influence of bryostatins on the larval settlement of other invertebrates has not been investigated, and its elucidation would expand our understanding of the ecological significance of the bryostatins. It is not yet clear which ' $E$. sertula' cells synthesize the rhizoid bryostatins or how the bryostatins ultimately become associated with the exterior of the rhizoid cuticle. We can infer that the surface-associated bryostatins prevent grazing on rhizoids as they do in larvae, however this remains to be tested in the rhizoids.

The development and growth of $B$. neritina in seawater, which contains a diverse microbial community, necessitates mechanisms for maintaining an exclusive, long-term association with ' $E$. sertula' within its tissues. The patterns of bryostatin and 'E. sertula' concentrations suggest regulation of the levels of both during particular periods in the $B$. neritina life cycle. It is possible that during 
reproductive periods, bryostatin synthesis is upregulated in the ovicells to load the larvae. Furthermore, the adherence of the ' $E$. sertula' cells to the pallial epithelium during the metamorphic movements of this tissue indicates the presence of surface adhesins on the host cells. The biochemical mechanisms that regulate the symbiont growth and synthesis of bryostatins within the ovicell, adult funicular system, and metamorphosing larva are critical areas of future research. Identifying the regions in the host that support high rates of symbiont growth and bryostatin synthesis will inform cultivation efforts of $E$. sertula, which continues to defy cultivation in the lab, as well as expand our understanding of fundamental features of chemical defense symbioses.

\section{Acknowledgements}

We thank C Sheehan, R McConaughey, D Edwards, E Kisfaludy, C Anderson and S Sudek for assistance with $B$. neritina collection. G Lim provided $B$. simplex and B. turrita larvae, A Newton helped with initial design of the bryostatin detection method and $\mathrm{H}$ Trapido-Rosenthal advised on protocols for settlement induction. We also thank Sandra Oster, two anonymous reviewers and an editor for comments that improved this manuscript. This work was funded by California Sea Grant (R/MP-88), the National Institutes of Health (grant 5R01CA079678-03) and the Scripps Institution of Oceanography Graduate Student Office. KHS was supported by the Los Angeles ARCS Foundation. SKD was supported by NSF Grant IOB 0345049.

\section{References}

Amann RI, Binder BJ, Olson RJ, Chisholm SW, Devereux R, Stahl DA. (1990). Combination of $16 \mathrm{~S}$ rRNAtargeted oligonucleotide probes with flow cytometry for analyzing mixed microbial populations. Environ Microbiol 56: 1919-1925.

Daniels R, Vanderleyden J, Michiels J. (2004). Quorum sensing and swarming migration in bacteria. FEMS Microbiol Rev 28: 261-289.

Davidson SK. (1999). Biology of the bryostatins in the marine bryozoan Bugula neritina: symbiosis, cryptic speciation and chemical defense. $\mathrm{PhD}$ dissertation, University of California San Diego, La Jolla.

Davidson SK, Allen SW, Lim GE, Anderson CM, Haygood MG. (2001). Evidence for the biosynthesis of bryostatins by the bacterial symbiont 'Candidatus Endobugula sertula' of the bryozoan Bugula neritina. Appl Environ Microbiol 67: 4531-4537.

DeVries DJ, Herald CL, Pettit GR, Blumberg PM. (1988). Demonstration of sub-nanomolar affinity of bryostatin 1 for the phorbol ester receptor in rat brain. Biochem Pharmacol 37: 4068-4073.

Gillor O, Carmeli S, Rahamim Y, Fishelson Z, Ilan M. (2000). Immunolocalization of the toxin latrunculin B within the Red Sea sponge Negombata magnifica. Mar Biotechnol 2: 213-223.
Gordon DP. (1977). The aging process in bryozoans. In: Woollacott RM, Zimmer RL (eds). Biology of Bryozoans. Academic Press: New York, pp 335-375.

Haygood MG, Davidson SK. (1997). Small-subunit rRNA genes and in situ hybridization with oligonucleotides specific for the bacterial symbionts in the larvae of the bryozoan Bugula neritina and proposal of 'Candidatus Endobugula sertula’. Appl Environ Microbiol 63: 4612-4616.

He XS, Fuqua C. (2006). Rhizosphere communication: quorum sensing by the rhizobia. J Microbiol Biotechnol 16: 1661-1677.

Hildebrand M, Waggoner L, Liu H, Sudek S, Allen S, Anderson C et al. (2004). BryA: an unusual modular polyketide synthase gene from the uncultivated bacterial symbiont of the marine bryozoan Bugula neritina. Chem Biol 11: 1543-1552.

Kraft AS, Smith JB, Berkow RL. (1986). Bryostatin, an activator of the calcium phospholipid-dependent protein kinase, blocks phorbol ester-induced differentiation of human promyelocytic leukemia cells HL-60. Proc Natl Acad Sci USA 83: 1334-1338.

Kuzirian AM, Epstein HT, Gagliardi CJ, Nelson TJ, Sakakibara M, Taylor C et al. (2006). Bryostatin enhancement of memory in Hermissenda. Biol Bull 210: 201-214.

Lim GE, Haygood MG. (2004). 'Candidatus Endobugula glebosa', a specific symbiont of the marine bryozoan Bugula simplex. Appl Environ Microbiol 70: 4921-4929.

Lindquist N, Hay ME. (1996). Palatability and chemical defense of marine invertebrate larvae. Ecol Monogr 66: 431-450.

Lopanik NB, Lindquist N, Targett N. (2004). Potent cytotoxins produced by a microbial symbiont protect host larvae from predation. Oecologia 139: 131-139.

Lopanik NB, Targett NM, Lindquist N. (2006). Ontogeny of a symbiont-produced chemical defense in Bugula neritina (Bryozoa). Mar Ecol Prog Ser 327: 183-191.

Lupp C, Ruby EG. (2005). Vibrio fischeri uses two quorumsensing systems for the regulation of early and late colonization factors. J Bacteriol 187: 3620-3629.

Miller MB, Bassler BL. (2001). Quorum sensing in bacteria. Annu Rev Microbiol 55: 165-199.

Parkinson DR, Arbuck SG, Moore T, Pluda JM, Christian MC. (1994). Clinical development of anticancer agents from natural products. Stem Cells 12: 30-43.

Pettit GR, Herald CL, Doubek DL, Herald DL. (1982). Isolation and structure of bryostatin 1. J Am Chem Soc 104: 6846-6847.

Salomon CE, Deerink T, Ellisman MH, Faulkner DJ. (2001). The cellular localization of dercitamide in the Palauan sponge Oceanapia sagittaria. Mar Biol 139: 313-319.

Schroder HC, Breter HJ, Fattorusso E, Ushijima H, Wiens M, Steffen R et al. (2006). Okadaic acid, an apoptogenic toxin for symbiotic/parasitic annelids in the demosponge Suberites domuncula. Appl Environ Microbiol 72: 4907-4916.

Sudek S, Lopanik NB, Waggoner LE, Hildebrand M, Anderson C, Liu HB et al. (2007). Identification of the putative bryostatin polyketide synthase gene cluster from 'Candidatus Endobugula sertula,' the uncultivated microbial symbiont of the marine bryozoan Bugula neritina. J Nat Prod 70: 67-74.

Sun MK, Alkon DL. (2005). Dual effects of bryostatin-1 on spatial memory and depression. Eur J Pharmacol 525: 171. 
Sun MK, Alkon DL. (2006). Bryostatin 1: pharmacology and therapeutic potential as a CNS drug. CNS Drug Rev 12: 1-8.

Wender PA, Cribbs CM, Koehler KF, Sharkey NA, Herald CL, Kamano Y et al. (1988). Modeling of the bryostatins to the phorbol ester pharmacophore on protein kinase-C. Proc Natl Acad Sci USA 85: 7197-7201.

Woollacott RM. (1981). Association of bacteria with bryozoan larvae. Mar Biol 65: 155-158.

Woollacott RM, Zimmer RL. (1977). Metamorphosis, ancestrulae, and coloniality in bryozoan life cycles.
In: Woollacott RM, Zimmer RL (eds). Biology of Bryozoans. Academic Press: New York, pp 91-142.

Woollacott RM, Zimmer RL. (1978). Metamorphosis of cellularioid bryozoans. In: Chia FS, Rice ME (eds). Settlement and Metamorphosis of Marine Invertebrate Larvae. Elsevier/North-Holland Biomedical Press: New York, pp 49-63.

Yool AJ, Grau SM, Hadfield MG, Jensen RA, Markell DA, Morse DE. (1986). Excess potassium induces larval metamorphosis in four marine invertebrate species. Biol Bull 170: 255-266. 